\title{
The Road to European Integration
}

\author{
Armin Cuyvers
}

A Bumpy but Rewarding Road...

The European Union (EU) has achieved a unique level of political and economic integration. More than 500 million European citizens share an area of Freedom Security and Justice and an internal market that forms the largest economic bloc in the world. 19 national currencies have been 'integrated' into a single European currency, further enabling trade and increasing wealth. To achieve and sustain such integration, strong institutions have been built, novel legal and political mechanisms have been developed, and substantial powers have been shared at the Union level, all whilst maintaining the ultimate authority and democratic legitimacy of the Member States.

This high level of integration has wielded enormous benefits in terms of wealth, stability and influence. For despite the vital importance of good law and institutions, part of the real secret behind integration is that it ultimately forms a win-win for all players involved. For states, citizens and businesses alike, integration can provide vital economic and political benefits. What is more, in our globalizing reality, integration is also necessary to retain the economic and political significance of individual states. As markets, companies and the digital world transcend borders, so must states transcend their own borders and cooperate to retain their relevance.

At the same time, European integration has been a long and bumpy road, and the process is far from complete. For despite its long-term benefits, it remains a challenge to properly structure regional integration and to overcome short-term obstacles and conflicts of interest. How, for example, to balance the influence and interests of different Member States, how to divide the benefits and costs of integration, or how to structure democracy at the supranational level? Over the years, therefore, the EU has faced many challenges and set-backs as it pioneered the process of regional integration and tried to adapt how we govern to the reality that needs to be governed. Brexit only forms the most recent example of such a set-back and of just how challenging it is to develop regional integration that is effective and legitimate, and that can resist short-term nationalistic reflexes, especially in times of (economic) crises and uncertainty. So far, however, the EU has always overcome such set-backs, 
usually deepening integration as a result, in part because of the ultimate desirability and necessity of regional integration as set out above, although the fallout of Brexit of course still has to become clear.

It is the long and bumpy road travelled by the EU that will be discussed in the different EU companion chapters in this book. These companion chapters provide concise overviews of different fields of Eu law and discuss the key legal tools that were developed to turn integration from an aspiration into a reality. Considering the comparative objective of this book, the primary focus of these companion chapters is on the foundational rules, mechanism and doctrines of EU law that still provide the basis for European integration today, and that might provide useful inspiration for East African integration now. For more comprehensive or specific discussions on particular issues of EU law each chapter will refer the reader to more specialized literature. In this way, the companion chapters also hope to function as a portal for those wanting to engage in more in depth comparative EAC-EU analysis on particular topics. ${ }^{1}$

Despite their comparative ambitions, the EU companion chapters of course fully recognize the significant differences between the EU and the EAC, and consequently the need for tailor-made EAC solutions that fit the unique potential of East Africa in the 21st century. Comparison can never be a cut-and-paste exercise. ${ }^{2}$ Nor do the EU companion chapters assume that the 'European way' is per definition the 'best' and should therefore always be followed. Quite the contrary: the EU offers more than enough failures and mistakes to learn from, and these failures are often at least as instructive as the EU successes. Instead of simplistically transplanting EU norms to the EAC, therefore, the aim of the companion chapters is first to distill the different legal solutions

1 For those interested in further exploring Eu law also see the Massive Open Online Course (моос) 'The Law of the European Union: An Introduction 'developed by the Europa Instituut of Leiden University and available online for free via Coursera.

2 See on the challenges of comparison inter alia V.C. Jackson, 'Comparative Constitutional Law: Methodologies', in: M. Rosenfeld and A. Sajó (eds) The Oxford Handbook of Comparative Constitutional Law (oup 2012), 54, V.C. Jackson, 'Methodological Challenges in Comparative Constitutional Law' 28 Penn State International Law Review (2010), 319, M. Tushnet, 'Comparative Constitutional Law', in: M. Reimann and R. Zimmermann (eds), The Oxford Handbook of Comparative Law (OuP 2006), 1226, G. Frankenberg, 'Comparing constitutions: Ideas, ideals, and ideology - toward a layered narrative', InternationalJournal of Constitutional Law (2006), 439, P. Legrand, 'The Impossibility of "Legal Transplants"' 4 Maastricht Journal of European and Comparative Law (1997), 111. and classically O. Kahn-Freund, 'On Uses and Misuses of Comparative Law', 37 Modern Law Review (1974), 1. 
that were developed to meet the different challenges of regional integration. Subsequently, in conjunction with the primary EAC chapters and preferably in a combined effort between EAC and EU experts, it can be further explored how such legal solutions may be translated and adapted to the EAC context. With the benefit of almost 60 years of European hindsight, such a joint effort could hopefully help the EAC to avoid some of the detours taken by European integration, shortening the path towards EAC integration and removing some of the bumps. This is especially so as the EAC has adapted significant parts of the EU institutional and legal framework in its Treaties and Protocols.

This first companion chapter discusses the development of the EU from a Community of six focused on Coal and Steel to a deeply integrated Union of 28 . Considering the limited size of this chapter and the rich history of European integration, the discussion focusses on the main developments and most formative crises. ${ }^{3}$ Consequently, this chapter first discusses the failed attempts at European integration that preceded the EU, as well as other forms of cooperation in Europe from which the EU should be distinguished. It then charts how the process of European integration got underway, and how it gradually widened and deepened as more and more Member States joined and European integration came to cover more and more policy areas. This discussion will include the different Treaties signed as well as some of the major crises and events faced by the $\mathrm{EU}$, both to present the whole picture of the integration process and to demonstrate how crises may actually form vital and integral parts of integration. The chapter concludes with a brief discussion of Brexit, the most recent fundamental challenge to European integration that may contain useful lessons for the EAC, including on the question of how to deal with the possible withdrawal of Partner States.

3 For more detailed discussions on the history of European integration and it main drivers see inter alia P. Craig \& G. De Búrca, EU Law: texts, cases and materials (OUP, 2015, 6th edition), D. Chalmers, G. Davies and G. Monti, European Union Law (CUP, 2010), G. Majone, Dilemmas of European Integration: The Ambiguities and Pitfalls of Integration by Stealth (OUP, 2005), A. Moravcsik, The Choice for Europes: Social Purpose and State Power from Messina to Maastricht (Cornell University Press, 1998), or G. Delanty, Inventing Europe: Idea, Identity, Reality (Macmillan, 1995). 

on Coal and Steel

The idea of uniting 'Europe' has been around for a long time, even if the meaning of 'Europe' itself has never been static. ${ }^{4}$ Several kings, emperors and dictators have obviously tried to 'unite' Europe by force. However, there also is a long history of proposals to unite Europe in a more peaceful and cooperative manner. In 1693, for example, William Penn already developed a confederal proposal for Europe in his 'Essay Towards the Present and Future Peace of Europe'. In 1814, the French philosopher Saint-Simon, even came surprisingly close to the EU institutional framework we find today, even planning the capital for his Union close to Brussels. ${ }^{5}$

These early ideas, however, never gained real traction. They went against the grain of European history, which, in the age of Westphalia, moved towards ever more centralized and powerful nation-states. ${ }^{6}$ Instead of cooperation and sharing authority, the trend was to concentrate authority in the state and to make the state increasingly absolute. Two world wars, however, drastically changed the near sacred status of the sovereign state. World War I lasted from 1914 until 1918, leaving over 16 million dead. After this war, the League of Nations was established, a kind of predecessor to the United Nations, to prevent future wars. This relatively weak intergovernmental organization, however, failed, and could not prevent a second World War from erupting between 1939 and 1945. Total deaths due do the Second World War are estimated between 60 to 80 million. This includes the systematic extermination of over 11 million people, mostly Jews, in the Holocaust.

Both world wars had truly brought home the devastating nature and effect of modern industrial warfare, especially once linked to nationalism and absolute nation-states. Once nationalism, centralized nation-states and modern weaponry were combined, the effects were simply unconscionable. Consequently,

4 See for example D. De Rougemont, The Idea of Europe (New York, MacMillian, 1965), G. Delanty, Inventing Europe: Idea, Identity, Reality (Basingstoke, Macmillian, 1995), J. Le Goff, The Birth of Europe (Oxford, Blackwell, 2005), or R. McKitterick, Charlemagne: the Formation of a European Identity (Cambridge, CUP, 2008).

5 See his 1814 'Plan de la Réorganisation de la société européenne', or 'Plan for the Reorganisation of the European Society'.

6 See for a further discussion of the Peace of Westphalia, traditionally seen as the 'birth' of the modern, sovereign nation-state, and the subsequent evolution of the concept of sovereignty in Europe A. Cuyvers, The EU as a Confederal Union of Sovereign Member Peoples, Exploring the potential of American (con)federalism and popular sovereignty for a constitutional theory of the EU, (Leiden, 2013). 
preventing future wars became of paramount importance. Never again, nie wieder, jamais, became the rallying cry for European integration, as well as for other international attempts to impose some limits and controls on European states. For if states cannot be trusted to always control themselves, the logical conclusion was that another layer of control, above the state, was necessary to provide a safe-guard. ${ }^{7}$

At the international level, the UN was established in 1945, with the UN Security Council receiving unique competences on the legal use of force. ${ }^{8}$ In Europe, the Council of Europe was established in 1949, with a focus on democracy, the rule of law and human rights. The Council of Europe, which today has 47 Members, is best known for the European Court of Human Rights (ECtHR) in Strasbourg, which applies the European Convention on Human Rights (ECHR). The core idea behind the ECHR is precisely to have a fundamental rights court outside and above the state, so that it can offer protection against the state where necessary. Primary protection of fundamental rights, therefore, remains at the national level, but the ECtHR forms a safeguard where the state fails to respect fundamental rights. The Council of Europe, however, should not be confused with the EU. The Council of Europe is an independent, separate international organization, with a different and more limited mandate. It also is a less far reaching form of integration, and does not even come close to the level and scope of supranational integration achieved in the EU.

The first step in the creation of what would become the $\mathrm{EU}$, however, was only taken with the famous Schuman declaration of 9 May 1950. ${ }^{9}$ In this declaration, largely drafted by Jean Monnet, Schuman proposed the creation of a European Coal and Steel Community:

Europe will not be made all at once, or according to a single plan. It will be built through concrete achievements which first create a de facto solidarity. The coming together of the nations of Europe requires the

7 This narrative obviously leaves out the often atrocious acts of European states outside the EU as, sadly enough, these acts never played as central a role in uniting Europe as the destruction European states visited on themselves.

8 See especially Title VII of the UN Charter and the powers of the UN Security Council contained therein.

9 On the failure of two other attempts concerning political and military integration see for example E. Fursdon, The European Defence Community: A History (Macmillan, 1980) and R. Cardozo, 'The Project for a Political Community (1952-2), in R. Pryce (ed), The Dynamics of European Union (Croom Helm 1987). 
elimination of the age-old opposition of France and Germany. Any action taken must in the first place concern these two countries.

With this aim in view, the French Government proposes that action be taken immediately on one limited but decisive point: It proposes that Franco-German production of coal and steel as a whole be placed under a common High Authority, within the framework of an organisation open to the participation of the other countries of Europe.

The pooling of coal and steel production should immediately provide for the setting up of common foundations for economic development as a first step in the federation of Europe, and will change the destinies of those regions which have long been devoted to the manufacture of munitions of war, of which they have been the most constant victims.

The solidarity in production thus established will make it plain that any war between France and Germany becomes not merely unthinkable, but materially impossible. The setting up of this powerful productive unit, open to all countries willing to take part and bound ultimately to provide all the member countries with the basic elements of industrial production on the same terms, will lay a true foundation for their economic unification.

This production will be offered to the world as a whole without distinction or exception, with the aim of contributing to raising living standards and to promoting peaceful achievements. With increased resources Europe will be able to pursue the achievement of one of its essential tasks, namely, the development of the African continent.

In this way, there will be realised simply and speedily that fusion of interest which is indispensable to the establishment of a common economic system; it may be the leaven from which may grow a wider and deeper community between countries long opposed to one another by sanguinary divisions.

By pooling basic production and by instituting a new High Authority, whose decisions will bind France, Germany and other member countries, this proposal will lead to the realisation of the first concrete foundation of a European federation indispensable to the preservation of peace.

Without condoning in any form the reference to Africa, the central idea behind the Schuman declaration was to create a supranational authority over Coal and Steel, which were at that time the two central commodities for industrialization and war. In addition, the declaration already contained the interconnection of peace and prosperity that was to become central to European integration. On the one hand, economic integration formed a tool to ensure 
peace: once key industries were integrated war would become an (economic) impossibility. On the other hand, economic development and increased prosperity also formed an end in itself for a Europe ravaged by war. Continued peace, moreover, would also contribute to prosperity as nothing undermines continued prosperity as armed conflict. ${ }^{10}$

The European Coal and Steel Community was established in $195^{2}$ by the six 'founding members' France, Germany, Italy, Belgium, Luxemburg and The Netherlands, and contained the vital supranational elements suggested by Schuman and Monnet. ${ }^{11}$ Most importantly, a supranational High Authority was established, the later Commission, which could take binding decisions within its own mandate. ${ }^{12}$ The supranational nature of the ECSC distinguished it from 'normal' intergovernmental organizations, and allowed it to be far more effective and successful.

\subsection{From Coal and Steel to the European Community}

In 1957, following the success of the ECSC, two additional organisations, both clearly supranational in character, were created: the European Atomic Agency (EAA), and the European Economic Community (EEC). ${ }^{13}$ In contrast to the ECSC and the EAA, however, the EEC was not limited to specific sectors such as coal and steel or atomic energy, but covered the entire economy. The EEA and the EEC were established by the same six countries that also pioneered the establishment of Coal and Steel Community.

Of these three organisations it is the EEC that developed furthest and contributed most to the economic integration in Europe. ${ }^{14}$ Its growth over the past decades, both in scope as in membership, has been quite impressive.

\footnotetext{
10 See on this combination also EU Chapter 9.

11 Treaty establishing the European Coal and Steel Community (Paris, 18 April 1951).

12 See further on this point EU Chapter 2.

13 The Treaty establishing the European Atomic Energy Community (Euratom) and the Treaty establishing the European Economic Community (also known as the Treaty of Rome), (Rome, 25 March 1957).

14 In fact the ECSC itself no longer exists. As the ECSC Treaty was concluded for a limited period of 50 years, it expired in 2002 with all the assets and activities of the ECSC being subsumed into the $\mathrm{EU}$.
} 


\subsubsection{Development of the EEC}

The development of the EEC was, of course, gradual, but certain crucial stages in its development can be singled out. After the initial successes and enthusiasm, the first critical challenge came in the 1960s and 1970s. During this time, and largely due to the political resistance by French president De Gaulle, the EEC had slowly retreated to a more intergovernmental way of functioning. In June 1965 the situation escalated when De Gaulle walked out of negotiations, and for more than half a year the French refused to participate at all, a situation that became known as the 'empty chair crisis'. This crisis was resolved in January of 1966 with the Luxembourg Accords, but at a very high price. Under the Luxembourg Accords, every Member State could declare that a certain proposal being discussed in the Council touched on 'very important national interest', which would then obligate the others not to vote on the proposal at all. De facto, the Luxemburg Accords gave every Member State a veto whenever they wanted to claim one, and they did so frequently. The increasingly frequent use of vetoes blocked decision-making, undermined the supranational assumptions underlying the EEC, and led to a long period of political stagnation. ${ }^{15}$

During this period of political stagnation, it was the European Court of Justice (CJEU) that kept the process of integration going, inter alia with its seminal judgments on the direct effect and supremacy of EU law, as well as on the free movement rights of companies and individuals. ${ }^{16}$ For when political decision-making on EU legislation was blocked, the CJEU was able to interpret and apply Eu primary law, as contained in the different Treaties, and develop it into an effective system of rights and obligations. The case law of the CJEU thereby helped to keep European integration alive and relevant, but also provided an impetus for the political revival of European integration and the internal market.

This revival came with Single European Act of 1986 (SEA), which was the first large Treaty amendment since $1957 .{ }^{17}$ The SEA placed the 'single market' at the forefront of European integration, and, with that renewed economic focus managed to energise the Communities. For example, it created an ambitious aim to finalize the internal market by 31 December 1992, created new competences to that end, and allowed decision-making by qualified majority, removing the blockage created by the Luxembourg Accords. ${ }^{18}$

\footnotetext{
15 See J-M. Palavret et al. (eds.) Visions, Votes and Vetoes: Reassessing the Luxembourg Compromise 40 Years On (Peter Lang, 2006).

16 See for a discussion of this seminal case law Eu Chapters 4 and 9-13.

17 The Single European Act (Luxembourg, 17 February 1986), oJ [1987] L169.

18 See further EU Chapter 9 on the SEA and its importance.
} 
The SEA indeed contributed to a new energy for European integration, especially concerning the internal market where a flurry of legislative activity ensued. Already in 1992, however, the EU was faced with a truly existential event: the fall of the Berlin Wall in November 1989 and the subsequent collapse of the Soviet Union. ${ }^{19}$ The fall of the Berlin Wall not only led to German reunification, and hence a major power shift in the EU, but also to fundamental questions as to the political nature of the $\mathrm{EU}$ and the role of the $\mathrm{EU}$ on the international stage.

\subsubsection{From European Community to Full European Union}

The new political reality could also be seen in the 1992 Treaty of Maastricht, an important milestone in European integration. ${ }^{20}$ Maastricht formally broadened the scope and ambitions of European integration to Common Foreign and Security Policy (CFSP) and Justice and Home affairs (JHA), taking it clearly beyond economic integration alone. At the same time, Member States were unwilling to grant supranational authority over such sensitive fields as justice and foreign policy. ${ }^{21}$ Consequently, Maastricht created the so-called 'temple' structure, a rather uncommon model in constitutional design. Three separate 'pillars' were created. The first pillar was formed by the former EEC, which was renamed the 'European Community (EC)' to reflect its extended ambit. This first pillar remained supranational in character. The Common Foreign and Security Policy (CFSP) and Justice and Home affairs (JHA) formed two separate, essentially intergovernmental, pillars. Jointly, these three pillars supported the 'roof' of the temple, being the European Union. At this stage of integration, therefore, the European Community remained the supranational heart of European integration, whereas the name 'European Union' only referred to the wider construct based on the three pillars.

The Treaty of Maastricht also introduced EU Citizenship and further empowered the European Parliament as part of a broader attempt to improve the democratic legitimacy and functioning of the EU. ${ }^{22}$ Moreover, it contained a commitment to the creation of an Economic and Monetary Union (EMU),

19 See on the enormous impact of this event for the EU inter alia L. van Middelaar, The Passage to Europe. How a Continent Became a Union (Yale University Press, 2014), chapter 6 .

20 Treaty on European Union (Maastricht Treaty) (7 February 1992, Maastricht), oJ [2992] C 191.

21 See further Eu Chapter 5 .

22 See further EU chapter 2 on the development of the European Parliament and EU Chapter 11 on the concept of EU Citizenship. 
including the introduction of a single currency (the euro), and provided a detailed roadmap for its development. ${ }^{23}$

The Treaty of Maastricht, therefore, contained several far reaching ambitions, but ran into severe difficulties. The ratification of the Treaty was first rejected in a Danish referendum, only received $51 \%$ of votes in a French referendum, and was heavily fought over in the Uk. Only after a second referendum in Denmark in May 1993 could the Treaty enter into force. The difficult and contested ratification of Maastricht proved a sign of a wider disenchantment with European integration, as popular support for the project decreased from well over $70 \%$ in 1990 to around 50\% in 1996.

Subsequent Treaties failed to address these concerns and the different problems associated with the Maastricht Treaty. The Treaty of Amsterdam, which came into effect on May 1st 1999 was markedly less ambitious in its goals and achievements. Besides renumbering the existing Treaties, the main alterations lay in the free movement of persons, the wider use of the co-decision procedure, and the introduction of a possibility of 'closer cooperation' between Member States. The main goal of the Amsterdam Treaty, which was to prepare the EU for the approaching enlargement with ten new Member States, was certainly not achieved, but rather postponed to the Nice Summit of 2000. The Treaty of Nice, however, also failed to achieve sufficient results. The compromises reached were complex and not sufficient to deal with the enlargement or the other structural challenges facing the EU.

Consequently, already one year after Nice, the 2001 Laeken declaration of the European Council called for a 'deeper and wider debate about the future of the European Union'. The Laeken declaration led to the creation of a 'European Convention' to discuss the future of the EU, and to draft a 'European Constitution' which would enable the EU to develop further and to deal more satisfactorily with the issues raised by enlargement. In 2004, the Convention indeed led to a new Treaty entitled the 'Treaty establishing a Constitution for Europe. ${ }^{24}$

The Constitutional Treaty was certainly no traditional, statal constitution and did not intend to create a European federation. At the same time, the new Treaty did purport to further constitutionalise European integration and reflect the deep integration reached in Europe..$^{25}$ In line with these constitutional

23 The EMU is discussed in more detail in EU Chapter 13.

24 OJ [2004] C 310.

25 See on the contested question of whether the EU Treaties constitute a Constitution inter alia B. De Witte, 'The European Union as an international legal experiment', in: G. de Búrca and J.H.H. Weiler, The Worlds of European Constitutionalism' (CUP, 2012), 
ambitions, the Constitutional Treaty was put to a vote in national referenda, where it suffered a humiliating defeat. On 29 May 2005, 55 per cent of the French voters said no, and on 1 June 2005 even 62 per cent of the Dutch voters rejected the Constitutional Treaty.

The precise grounds for these rejections can be debated, and over two-thirds of all Member States did ratify, but the rejection of the Constitutional Treaty was a major set-back for the EU. After a two year 'period of reflection', work was started in 2006 on what would become the Lisbon Treaty. ${ }^{26}$ In 2007 a relatively short Intergovernmental Conference (IGC) was held that hammered out a new Treaty largely based on the text of the Constitutional Treaty. ${ }^{27}$ The new Treaty was signed on 13 December in Lisbon, hence officially becoming 'the Lisbon Treaty'. ${ }^{28}$ The Lisbon Treaty survived the national ratification process and different constitutional challenges brought against it, though at a further price in legitimacy, and entered into force on 1 December $2009 .{ }^{29}$ Consequently, the Treaty of Lisbon established the legal framework for the Eu currently in place.

\subsubsection{The Legal Framework after Lisbon}

Since the Treaty of Lisbon, the EU is based on two Treaties of equal legal value: the Treaty on European Union (TEU) and the Treaty on the Functioning of the

19, D. Grimm, 'Types of Constitutions', in: M. Rosenfeld and A. Sajó (eds) The Oxford Handbook of Comparative Constitutional Law (OuP, 2012), 99, A. Von Bogdandy and J. Bast (eds), Principles of European Constitutional Law (2nd edn, Hart, 2010), N. Walker, 'Big 'C' or small 'c" 12 European Law Journal (2006), 12, S. Douglas-Scott, Constitutional Law of the European Union (Pearson 2002), or G. De Búrca, 'The Institutional Development of the EU: A Constitutional Analysis', in: P. Craig and G. de Búrca (eds), The Evolution of EU law (OUP, 1999), 55 .

26 See European Commission, The Period of Reflection and Plan D (Com(2006)212,2 and the EU Council Declaration of 25 March 2007, par. 3 .

27 See for an impressive overview M. Dougan, 'The Treaty of Lisbon 2007: Winning Minds, not Hearts' 45 CMLRev (2008), 617.

28 Treaty of Lisbon (13 December 2007, Lisbon), oJ [2007] C 306.

29 See especially in this regard the judgment by the German Constitutional Court on the compatibility of the Lisbon Treaty with the German Constitution in BVerfGE, 2 BvE 123,267, 2 BvE 2/08 (2009) Lissabon Urteil as discussed inter alia by D. Grimm, 'Comments on the German Constitutional Court's Decision on the Lisbon Treaty. Defending Sovereign Statehood against Transforming the European Union into a State', 5 European Constitutional Law Review (2009), 353, C. Schönberger, 'Lisbon in Karlsruhe: Maastricht's Epigone at Sea', 10 German Law Journal (2009), 1201, and F. Schorkopf, 'The European Union as An Association of Sovereign States: Karlsruhe's Ruling on the Treaty of Lisbon; 10 German Law Journal (2009), 1220. 
European Union (TFEU). ${ }^{30}$ In addition, Article 6 TEU declares that the Charter of Fundamental Rights of the European Union shall have the same legal value as the Treaties. Even though it was not politically feasible to include the Charter directly into the text of the Treaties, therefore, the Charter does form part of EU primary law and has the same hierarchical status as the TEU and the TFEU. ${ }^{31}$

Importantly, Lisbon also removed the pillar structure introduced by the Treaty of Maastricht. Formally, therefore, there are no more pillars and the European Community no longer exists but has been replaced by the European Union. This unification of EU law was one important aim of Lisbon. At the same time, however, Member States were still not willing to subsume foreign policy under a supranational approach. Consequently, Title $\mathrm{v}$ of the TEU creates a special, largely intergovernmental regime for the Union's external action and the Common Foreign and Security Policy (CFSP). The result of this special regime can be described as a kind of 'hidden' pillar for external relations. Within this hidden pillar Member States remain the key actors in most areas of external policy, excluding areas such as trade. ${ }^{32}$

With the Treaty of Lisbon, two decades of almost constant Treaty change and turmoil came to a close. In these 20 years of Treaty making the EEC developed into a three pillared temple capped by a European Union, only to subsequently morph into a complete European Union with its own citizens and currency. During these decades, however, multiple important factors remained constant as well, including many of the foundational doctrines of EU law and free movement set out in later chapters. In addition, the EU retained its key focus on peace and prosperity, even if new objectives and competences were added.

Considering the significant political and legal difficulties encountered during these Treaty changes, and because finding unanimity with 28 Member States has proven far from easy, the expectation after Lisbon was that no major Treaty revision would be attempted for at least some time, even though the project of integration itself is of course far from finished. ${ }^{33}$ The prospect of Brexit may alter this prediction, even though it may also be possible to deal

30 The Treaty of Lisbon only served to create these two Treaties, meaning one refers to the provisions in these Treaties directly, and not to the Treaty of Lisbon as such when citing Eu law.

31 See also EU Chapter 3 on the hierarchy of norms within EU law and EU Chapter 6 on the application and scope of the Charter.

32 See on the special nature and status of external relations and the CFSP further EU Chapter 5 .

33 See for the rules on Treaty change Article 48 TEU. Further see on the use of international law instrument where Treaty change proved unfeasible, for example during the euro crisis, EU Chapter 13. 
with a withdrawal of the UK from the EU without opening the 'Pandora's box' of general Treaty revision, in which many Member States may seek to change the fundamental set-up of the EU in their own (short-term) interests. Before we turn to a brief discussion of Brexit, and the likelihood of a first ever reduction in EU membership, however, the next section first describes the enlargement of the EU from a group of six to a group of 28 Member States, an important process that should be considered in parallel with the political and legal development set out above.

\subsubsection{Enlarging the EU}

As indicated above, the EU started out as a Community of six 'Founding Members', being Germany, France, Italy, The Netherlands, Belgium and Luxembourg. From the very start, however, the relevant Treaties always envisaged the accession of new members. ${ }^{34}$ An option that has been intensively used, and has had a major impact on the nature and development of the EU. ${ }^{35}$

After accession of the UK had been blocked by De Gaulle in 1961 and 1967 , the first enlargement of the EU took place in 1973 when Denmark, Ireland and the UK joined. In 1981 Greece joined the $\mathrm{EU}$ as well, with Spain and Portugal joining in 1986 and Austria, Finland and Sweden becoming Member States in 1995. The biggest single enlargement took place in 2004 when ten primarily Eastern European countries joined the EU, being Cyprus, the Czech Republic, Estonia, Hungary, Latvia, Lithuania, Malta, Poland, Slovakia and Slovenia. In 2007, these countries were joined by Bulgaria and Romania, which were not yet deemed ready in 2004. The last enlargement took place in 2013 when Croatia became the 28th Member State of the EU. At the time of writing, moreover, Albania, The former Yugoslav Republic of Macedonia, Montenegro, and Serbia are in the waiting room wanting to join the EU, albeit that for most, accession may take a very long time. Bosnia and Herzegovina and Kosovo have been promised the prospect of joining when they are ready. Turkey forms a very special case as its accession to the EU was already envisioned by the 1963 Ankara Association agreement, yet its accession currently seems further away than ever due to growing political tensions and conflicts.

34 Art. 237 of the Treaty of Rome, for example, already provided that 'any European state may apply to become a member of the Community'.

35 See for an overview and analysis, including of the 'enlargement fatigue' the may have arisen by now, C. Hillion, 'EU Enlargement', in: P. Craig and G. De Búrca (eds): The Evolution of EU Law (2nd edn., OUP 2011), 187 et seq. 
Even if the EU may currently suffer from 'enlargement fatigue', one of the open questions of EU integration therefore remains: 'where does Europe stop'? To accede, however, candidate countries have to follow an increasingly long and arduous path. To begin with, any state that wishes to join must first request permission to become a member from the Council. ${ }^{36}$ The Council then decides by unanimity, after consulting the Commission and receiving the assent of the European Parliament. If these requirements are met, an accession agreement will be negotiated with the applicant, usually with the Commission negotiating on behalf of the $\mathrm{EU}$. If an accession agreement is reached this agreement must then be ratified unanimously by all the Member States. ${ }^{37}$

\subsubsection{Downsizing the EU?}

At the time of writing, however, the EU is more concerned with existing Member States leaving the EU than new Member States joining. On 23 June $2016,51.9 \%$, or 17.410 .742 of the British voters chose to leave the EU. With a turnout of $72,2 \%$, a large minority of $48,1 \%$, or 16.141 .241 of the voters, opted to remain. The 'Leave' camp therefore won the day with a difference of 3,8\% or 1.269.501 votes. ${ }^{38}$ The new British Prime Minister, Theresa May, has since indicated that 'Brexit means Brexit' — whatever that may mean by itself-and that she intends to start the formal procedure for withdrawal before the end of March 2017. ${ }^{39}$

The precise outcome of Brexit will largely be decided on the field of politics, and not in the legal arena. In addition, with the withdrawal of a Member State, the EU is entering new territory, with very little precedents to guide it. ${ }^{40}$ Nevertheless, law will certainly have a role to play, and there are at least several

${ }_{3} 6$ See, reaffirming this notion even in the face of impressive enlargement to the East, the 1992 European Council Conclusions (EC Bulletin 6-1992, 1.4.) together with the conditions established for such accession in Copenhagen the next year. See also K.E. Smith, 'The Evolution and Application of Eu Membership Conditionality', in: M. Cremona (ed), The enlargement of the European Union (OUP 2003), 105 et seq.

37 Art. 49 TEU.

38 The outcome of the referendum therefore invalidates the earlier 'deal' between Cameron and the other 27 Heads of State and Government, see par. 4 of the European Council Conclusions of 19 February 2016, EUCO 1/16.

39 See for example the speech of May on 2 October 2016 to the conservative convention in Brighton.

40 Contrary to what is sometimes claimed, the cases of Algeria and Iceland do not provide relevant guidance, see A. Tatham, “'Don't Mention Divorce at the Wedding, Darling!” EU Accession and Withdrawal after Lisbon' in Andrea Biondi, Piet Eeckhout and Stefanie Ripley (eds), EU Law after Lisbon (OuP 2012), 143 and F. Weiss, 'Greenland's Withdrawal from the European Communities' (1985) $10 \mathrm{ELR}, 173$. 
rules and principles that will guide and influence the process of Brexit. Several of the most important ones will be briefly set out below, focusing on the nature and background of Article $50 \mathrm{TEU}$, the process for the withdrawal, and the nature and number of agreements that will to be concluded for Brexit to become a reality. ${ }^{41}$

\subsubsection{The Nature and Background of Article 50 TEU}

Long before the Treaty of Lisbon, the general consensus was that Member States could leave the EU. ${ }^{42}$ After all, it was hardly conceivable that the EU could keep a Member State in against its will, even though the precise modalities of leaving were far from clear. ${ }^{43}$ The right to leave the EU, however, was only explicitly recognized in Article I-6o of the Constitutional Treaty. After the rejection of this Treaty, as discussed above, the right to withdraw from the EU was codified by the Treaty of Lisbon in Article 50 TEU, which reads:

41 For further analysis please see P. Craig, 'Brexit: a drama in six acts' 2016 (4) European Law Review, 447, N. Walker, 'The European Fallout' German Law Journal Brexit Supplement (2016) 126, G. Davies, 'What Does It All Mean?', German Law Journal Brexit Supplement (2016) 7, B. De Witte, 'Near-membership, partial membership end the EU constitution', (2016) (4) European Law Review, 471, R.J. Friel, 'Providing a Constitutional framework for withdrawal from the EU: Article 59 of the Draft European Constitution' (2004) 53 ICLQ, p. 407, S. Berglund, 'Prison or Voluntary Cooperation? The Possibility of Withdrawal from the European Union' (2006) 29 Scandinavian Political Studies, p. 147, F. Harbo, 'Secession Right-An Anti-Federal Principle? Comparative Study of Federal States and the EU' (2008) 1 Journal of Politics and Law, p. 132, J. Herbst, 'Observations on the Right to Withdraw from the European Union: Who are the "Masters of the Treaties"?' (2005) 6 GLJ, 1755, H. Hofmeister, “'Should I Stay or Should I Go?”-A Critical Analysis of the Right to Withdraw From the EU' (2010) 16 ELJ, 589, A. Lazowski, 'Withdrawal from the European Union and Alternatives to Membership' (2012) 37 ELRev, 523, P. Nicolaides, 'Withdrawal from the European Union: A Typology of Effects' (2013) $20 \mathrm{MJ}$, 209, Jean Claude Piris, 'Should the UK withdraw from the EU: legal aspects and effects of possible options', Fondation Robert Schuman / European Issues n ${ }^{\circ} 355$ / 5th May 2015, A. Tatham, "'Don't Mention Divorce at the Wedding, Darling!" EU Accession and Withdrawal after Lisbon' in A. Biondi, P. Eeckhout and S. Ripley (eds), EU Law after Lisbon (2012), 128, and last but far from least, C. Hillion, 'Accession and Withdrawal in the Law of the European Union', in: A. Arnull and D. Chalmers (eds): The Oxford handbook of European Law (OUP 2015), 126.

See also A. Cuyvers, The EU as a Confederal Union of Sovereign Member PeoplesExploring the potential of American (con)federalism and popular sovereignty for a constitutional theory of the EU (Diss. Leiden, 2013), 88 a.o., as well as K. Widdows, 'The Unilateral Denunciation of Treaties Containing no Denunciation Clause' (1983) 53 British Ybk Intl L, 102 and paragraph 55 of the Maastricth Urteil (BVerfGE 89, 155) of the German Constitutional Court.

43 Cf. K. Lenaerts and P. van Nuffel, Constitutional Law of the European Union (Thomson, 2005), 363 . 
1. Any Member State may decide to withdraw from the Union in accordance with its own constitutional requirements.

2. A Member State which decides to withdraw shall notify the European Council of its intention. In the light of the guidelines provided by the European Council, the Union shall negotiate and conclude an agreement with that State, setting out the arrangements for its withdrawal, taking account of the framework for its future relationship with the Union. That agreement shall be negotiated in accordance with Article 218(3) of the Treaty on the Functioning of the European Union. It shall be concluded on behalf of the Union by the Council, acting by a qualified majority, after obtaining the consent of the European Parliament.

3. The Treaties shall cease to apply to the State in question from the date of entry into force of the withdrawal agreement or, failing that, two years after the notification referred to in paragraph 2, unless the European Council, in agreement with the Member State concerned, unanimously decides to extend this period.

4. For the purposes of paragraphs 2 and 3 , the member of the European Council or of the Council representing the withdrawing Member State shall not participate in the discussions of the European Council or Council or in decisions concerning it.

5. A qualified majority shall be defined in accordance with Article 238(3) (b) of the Treaty on the Functioning of the European Union.

6. If a State which has withdrawn from the Union asks to rejoin, its request shall be subject to the procedure referred to in Article 49.

This affirmation and codification of the right to withdraw served several purposes. Firstly, it was an important symbolical recognition of the ultimate sovereignty of the Member States. They remained the ultimate Herren der Verträge, or Masters of the Treaty. ${ }^{44}$ This recognition also was intended as a reassurance and legitimization of deeper integration: as Member States could always leave, the implication was that any deeper integration confirmed their implicit consent. $^{45}$

44 A. Tatham, “'Don't Mention Divorce at the Wedding, Darling!” EU Accession and Withdrawal after Lisbon' in A. Biondi, P. Eeckhout and S. Ripley (eds), EU Law after Lisbon (2012), 148.

45 C. Hillion, 'Accession and Withdrawal in the Law of the European Union', in: A. Arnull and D. Chalmers (eds): The Oxford handbook of European Law (oup 2015), 126, F. Harbo, 'Secession Right-An Anti-Federal Principle? Comparative Study of Federal States and the EU' (2008) 1 Journal of Politics and Law, 132. 
Secondly, Article 50 TEU was intended to draw the question of withdrawal within the scope of Eu law itself. Instead of question of Public International Law, withdrawal from the Union should become a question of Eu law itself.46 Thirdly, Article 50 TEU was also intended, at least partially, to make the process of leaving the $\mathrm{EU}$ unattractive. As will be discussed further below, for example, the withdrawing Member State is placed in a difficult negotiation position by the short two-year period in principle provided to complete the withdrawal. ${ }^{47}$ These different aims and objectives of Article 50 TEU should be kept in mind when interpreting and applying this brief, rather open, and sometimes vague provision.

\subsubsection{The Process of Withdrawal under Article 50 TEU}

Article 50 TEU provides that a Member State must first decide to withdraw from the Union 'in accordance with its own constitutional requirements.' Subsequently, the Member State must 'notify the European Council of its intention' to leave. ${ }^{48}$ The formal process of withdrawal only starts after a notification has been handed in. Until the UK hands in its notification, therefore, nothing changes in its legal position under EU law, and the EU is formally not even allowed to open negotiations with the UK on its exit.49

Once a notification has been handed in, the question may arise if a Member State may also revoke its notification to withdraw. One could argue that the two-year period in Article 50 TEU would be undermined if a Member State could revoke its notification, and that the option of revoking a notification might allow abuse by Member States. ${ }^{50}$ Indeed the parties and the UK High

46 See for an alternative view L.F.M. Besselink, 'Beyond Notification: How to Leave the Union without Using Article 5o TEU', U.K. Const. L. Blog (3oth Jun 2016) (available via <http:// ukconstitutionallaw.org >).

47 Cf. J. Herbst, 'Observations on the Right to Withdraw from the European Union: Who are the "Masters of the Treaties"?' (2005) 6 GLJ, 1757-8. At the same time the two year limit also forms a protection for the Member State that wants to withdraw, as it cannot be kept in the $\mathrm{EU}$ against its will.

48 As we have seen so far, this has raised the question of UK constitutional law if the UK government is allowed to submit a notification under the Royal Prerogative, or whether it needs an act of Parliament to do so. At the time of writing, the appeal to the Supreme Court against the High Court decision in R (on the application of Miller and Dos Santos) v Secretary of State for Exiting the European Union [2016] EWHC 2768 is still pending.

49 See also point two of the statement after the informal European Council of 27 to 29 June 2016.

5o See for example S. Lechner en R Ohr, 'The Right of Withdrawal in the Treaty of Lisbon: A Game Theoretic Reflection on Different Decision Processes in the EU,' CEgE 
Court in $R$ (on the application of Miller and Dos Santos) $v$ Secretary of State simply assume that revoking a notice is not possible, and that a notice, once given, therefore means a one way ticket to leaving the $\mathrm{EU} .{ }^{51}$

On closer inspection, however, the more correct interpretation seems to be that a notification under Article 50(2) TFEU can be revoked. To begin with, it is hard to imagine that the European Council would actually refuse a Member State to remain in the EU, certainly if the revocation of the notification to withdraw was given after a new election or a new referendum. In addition, however, it can be argued that a refusal to accept the revocation of a notification of withdrawal would also violate the EU's obligation of sincere cooperation, its obligation to strive towards an 'ever closer union' and its obligation to protect and safeguard the EU citizenship of all British subjects that stand to loose their citizenship after a Brexit. ${ }^{52}$

Once a notification has been given by the UK, however, a two year clock starts to tick. If no withdrawal agreement has been agreed and entered into force within two years, the UK will automatically and unilaterally leave the EU without any agreement on its withdrawal or its new relation with the EU. ${ }^{53}$ This scenario is one road towards the so called 'hard Brexit' and can be compared to the scenario where one partner comes home and discovers that the locks have been changed.

Article 50(3) TEU, however, does allow the European Council, by unanimity and with the consent of the UK, to extend this period. Moreover, Article 50(3) TEU does not limit the length or the number of such extensions that may be agreed. The requirement of unanimity, however, means that any Member State may veto an extension, thereby potentially driving the UK towards a hard exit. ${ }^{54}$

During the negotiations on its withdrawal, moreover, the UK remains a full Member of the EU, with all the rights and all the obligations of an EU Member.

Discussion Papers, No. 77, October 2008, Center for European, Governance and Economic Development research, Georg-August-Universität, Göttingen (2008), p. 4. Available via <http://www.uni-goettingen.de/de/6og2o.html>.

$5^{1} \quad \mathrm{R}$ (on the application of Miller and Dos Santos) v Secretary of State for Exiting the European Union [2016] EWHC 2768, par. 4.

$5^{2}$ See by analogy Case C-135/08 Rottmann ECLI:EU:C:2010:104 and Case C-34/o9 Zambrano ECLI:EU:C:2011:124.

53 Article 50(3) TEU.

54 Cf on this point the testimony by Sir David Edward concerning the risks for the UK in assuming an extension will be granted, as cited in par. 44 of the House of Lords European Union Committee Report of 4 May 2016 'The process of withdrawing from the European Union', available via <http://www.publications.parliament.uk/pa/ld201516/ldselect/ldeu com/138/138.pdf >. 
This also means that any extension of the two year period automatically lead to a prolonged EU membership of the UK, which might be politically unacceptable to the more impatient Brexiteers. The only exception to the rights of the UK after it notifies its intention to leave is that the UK Prime Minister and UK ministers may no longer 'participate in the discussions of the European Council or Council or in decisions concerning it.' The extent of this conclusion will depend on how broad or narrow an interpretation is given to the vague concept of 'concerning it.'55

\subsubsection{The Outcome: Two or Three Agreements?}

A last point to be addressed, aside from the content of the new relationship between the EU and the UK which will not be discussed here, is how many and what kind of agreements need to be concluded to realize a Brexit, and what the relation between these agreements must be. ${ }^{56}$ Article 50 TEU itself clearly requires at least two agreements: one agreement on the withdrawal itself and one, probably far more elaborate, agreement on the new relation between the EU and the UK. ${ }^{57}$

Crucially, both agreements have a different legal basis, and therefore have to be adopted under different procedures. The withdrawal agreement is based on Article 50 TEU itself, and forms an agreement between the EU and the UK alone. As discussed, this withdrawal agreement under Article $5^{0} \mathrm{TEU}$ has to be approved by the European Parliament and concluded by the Council by qualified majority. With the exception of the UK, therefore, the other Member States will not be parties to this withdrawal agreement, which also means

55 See on this point C. Hillion, 'Accession and Withdrawal in the Law of the European Union', in: A. Arnull and D. Chalmers (eds): The Oxford handbook of European Law (oup 2015), 126, as well as the Editorial Comments of the Common Market Law Review on Brexit, 53 (2016) Common Market Law Review, 1.

56 For an overview of the different models for the new relationship between the EU and the UK, none of which seem to offer much hope, see inter alia S. Dhingra en T. Sampson, 'Life after Brexit: What are the UK's options outside the European Union?' Centre for Economic Performance, London School of Economics Working PaperBrexit o1, and нм Government, 'Alternatives to membership: possible models for the United Kingdom outside the European Union' March 2016, available via <https://www.gov.uk/ government/uploads/system/uploads/attachment_data/file/504604/Alternatives_to_ membership_-_possible_models_for_the_UK_outside_the_EU.pdf $>$.

57 Cf. also the House of Lords European Union Committee Report of 4 May 2016 'The process of withdrawing from the European Union', point 31. See also A. Tatham, '"Don't Mention Divorce at the Wedding, Darling!” EU Accession and Withdrawal after Lisbon', in: A. Biondi, P. Eeckhout en S. Ripley (red.), EU Law after Lisbon, (OUP, 2012), 128. 
that the withdrawal agreement does not require ratification by the individual Member States.

The agreement on the new relation, however, will almost certainly be a mixed agreement between the EU and the 27 remaining Member States on the one side, and the UK on the other. ${ }^{58}$ This agreement will most likely be based on Articles 37 TEU and 217 and 218 TEU concerning respectively the CFSP and association agreements. Consequently, the agreement on the new relationship will first have to be approved by the European Parliament and subsequently adopted by unanimity in the Council. ${ }^{59}$ Subsequently, however, because of its mixity, the agreement on the new relationship will also have to ratified by the UK and each of the 27 remaining Member States. In turn, these national ratifications may lead to additional referenda or constitutional challenges. ${ }^{60}$

The procedure for the withdrawal agreement, therefore, is already simpler and more straightforward than the procedure for the agreement on the new relationship. In addition, the substance of the agreement on the new relation is also far more complex and extensive than the substance of the withdrawal agreement, which could in theory be one paragraph. To illustrate, CETA, the trade agreement between the $\mathrm{EU}$ and Canada, which is legally and politically less complex than Brexit, already took more than seven years, and a successful completion is far from certain.

Because the agreement on the new relation is procedurally and substantively far more complex than the withdrawal agreement, however, it is likely that the withdrawal agreement can be completed before the agreement on the new relationship. In addition, it is also unlikely that a comprehensive new agreement on the new relationship between the EU and the UK can even be completed within the two year period. This creates a serious problem as in terms of substance and effect the withdrawal agreement and the agreement on the new relationship are difficult to separate.$^{61}$ After all, if the withdrawal agreement enters into force before the agreement on the new relationship is in place, the UK is de facto kicked out of the EU without a new deal, and has to negotiate its new relationship with the EU from outside the EU and its internal market.

\footnotetext{
$5^{8}$ See further EU Chapter 5 on the concept of mixed agreements.

59 Article 218(8) vwEU.

6o See also Editorial Comments, (2016) 53 Common Market Law Review, 1.

61 See also B. De Witte, 'Near-membership, partial membership end the EU constitution', (2016) (4) European Law Review, 471.
} 
If one wants to avoid such an indirect hard Brexit, only two options seem available, and both are problematic. The first option is to link the entry into force of the withdrawal agreement to the entry into force of the agreement on the new relationship. This would mean that the UK would only withdraw from the Union after the entire agreement on the new relationship has been finalised and ratified by the EU and all 27 Member States. The price to be paid for this approach, which could guarantee a seamless transition to the new status of the UK, is a prolonged EU membership of the UK. After all, it is almost certain that a comprehensive agreement on the new relationship cannot be concluded and ratified within two years. It may be difficult for the British government to convince the Leave supporters that they should wait so long for their 'liberation' from the EU, and the Brexiteers would want to push a Brexit through before the general elections that must ultimately be held on 7 May 2020.

The second option is to link the withdrawal agreement to a third, transitional agreement. This transitional agreement would govern the relationship between the EU and the U K after Brexit for as long as it takes to conclude a final agreement on the new relation. ${ }^{62}$ The problem of this second option, however, is that concluding a transitional or interim agreement may be almost as complex and time consuming as concluding the final agreement on the new relationship itself. For, to begin with, the transitional agreement will have to cover many of the same points as the final agreement. In addition, the transitional agreement will inevitably form a benchmark for the final agreement and may be in place for a long time, meaning all parties may negotiate just as hard as for the final agreement.

If it proves impossible to find an agreement on a transitional agreement within the period of two years, however, we seem left with a choice between a hard Brexit, and a seriously prolonged EU Membership of the UK. Neither of these choices is very appealing, but this is of course primarily due to the fundamentally flawed assumption behind Brexit that it is possible to enjoy the benefits of integration without sharing a certain amount of sovereignty at the regional level, as the long and bumpy road towards EU integration has illustrated.

62 C. Hillion, 'Accession and Withdrawal in the Law of the European Union', in: A. Arnull en D. Chalmers (red.), The Oxford handbook of European Law, (OUP, 2015), 126. 